\title{
Questions on Immunization and Vaccination and Short Answers
}

\author{
Bağışıklama ve Aşı ile Illgili Sorular ve Kısa Cevaplar
}

\author{
Ateş Kara(ID) \\ Division of Pediatric Infectious Diseases, Department of Pediatrics, Hacettepe University School of Medicine, Ankara, Turkey
}

Cite this article as: Kara A. Questions on immunization and vaccination and short answers. J Pediatr Inf 2021;15(3):e195-e196.

Question 1: How should we proceed once an infant in the routine vaccination program is found out to be SARS-CoV-2 positive?

The generally accepted approach and recommendations of the Ministry of Health, World Health Organization (WHO) and other authorities (Centers for Disease Control and Prevention of the United States of America, NICE guideline of the United Kingdom) are to follow the routine vaccination program for children and adults without retardment during the COVID-19 period. However, in this case, the recommendation of the Ministry of Health is to defer vaccination (1). Independent of the symptoms, the infant's vaccination should be deferred until the end of the quarantine period and the vaccine should be administered to the infant following the termination of the quarantine period in accordance with the rules. The fundamental objective here is to eliminate the probable contact risk posed on healthcare workers. The recommendation of the American Pediatric Academy is also as such. In cases where the mother is tested positive but the infant negative, the general follow-up recommended by authorities is to routinely follow the infant and implement the vaccination schedule $(2,3)$. However, the mother is expected to abide by quarantine rules and the infant's follow-up must be realized by a family member known to be negative for SARS$\mathrm{CoV}-2$. If a negative family member cannot bring the infant for follow-up and/or vaccination, it would be appropriate for the vaccination and follow-up of the infant to take place after the termination of the mother's quarantine period.

Question 2: What is the difference between contraindications and precautions in vaccine practices?

Contraindications to vaccination, generally speaking, are conditions under which severe and life-threatening adverse effects associated with the planned vaccine constitute high risk for the person. The vaccine should not be administered under such a circumstance. Contraindication to vaccines is generally found on their summary of product characteristics and directions for use. However, in case the obtained data is very limited or in case the possible risks are high despite not being clearer, healthcare authorities may assess a vaccine contraindicated to a specific condition or persons.

Precautions to vaccination are conditions in a recipient that may increase the risk of severe adverse effects. This condition might cause diagnostic delay in some cases or may compromise the ability of the vaccine to produce the intended level of protection and immunity. For instance, vaccination of an individual with moderate or severe disease may make it difficult to make a diagnosis for the individual's possible clinical picture due to the effect of the vaccine or its adverse reactions on the individual's clinical picture. If a precaution is present, the administration of the vaccine can be deferred when there is no problem in reaching the individual and deferral of the vaccine does not put the

Correspondence Address / Yazışma Adresi

Ateş Kara

Hacettepe Üniversitesi Tıp Fakültesi,

Çocuk Sağlığı ve Hastalıkları Anabilim Dalı,

Çocuk Enfeksiyon Hastalıkları Bilim Dalı,

Ankara-Türkiye

E-mail: ateskara@hacettepe.edu.tr

Received: 01.09.2021 
individual at risk. Furthermore, the decision to administer the vaccine must be made by evaluating the possible advantages of administering the vaccine and the probable risks that may occur when a condition accepted as a precaution develops.

Question 3: Is there a contraindicated vaccine in infants and adults with G6PD deficiency? Is there a different aspect to pay attention to during vaccine administration?

G6PD deficiency that may be faced due to prolonged jaundice during the neonatal period is a relatively rare clinical entity which continues for life and progresses with hemolysis of erythrocytes and attacks. Glucose 6 phosphate dehydrogenase (G6PD) deficiency is a hereditary disease genetically transmitted between generations and causes erythrocyte destruction due to specific foods, stress, drugs and infection. Since it is recessive on the $\mathrm{X}$ gene, it is seen more commonly in males, and it is more often for males to be symptomatic. However, a clinical manifestation can be observed in females in the event of a mutation in one of the two copies of the G6PD gene. Some female patients may even have clinical findings as severe as male patients. Severe clinical manifestations occur when there is no glucose 6 phosphate dehydrogenase or when it is severely deficient, and erythrocyte destruction is seen in the event of consuming foods like broad bean, taking drugs and having an infection, which all cause serious oxidative stress on erythrocytes. It is relatively seen more frequently in the Eastern Mediterranean, Asia and Africa. The individuals are usually asymptomatic and may not even have any complaints throughout their lives. However, despite rare, G6PD deficiency can be seen in individuals with chronic hemolytic anemia.

By preventing infections that may cause attacks with vaccines, the development of clinical complaints in patients can be prevented. Hemolytic anemia can develop in individuals with G6PD deficiency either by viral or bacterial infections. Until today, the administered vaccines have not shown any risks in patients with G6PD deficiency. In this respect, vaccines do not constitute a risk in individuals with G6PD deficiency.

In light with this information, individuals with G6PD deficiency can be vaccinated without taking any additional measures in places administering routine vaccines. With the information at hand, there is no risk for SARS-CoV-2 (COVID-19) vaccines developed in different platforms.

\section{References}

1. T.C. Sağlık Bakanlığı COVID-19 Bilgilendirme Platformu. Available from: https://covid19.saglik.gov.tr [CrossRef]

2. American Academy of Pediatrics. 2019 Novel Coronavirus COVID-19 Infections. Available from: https://www.aap.org/en/pages/2019-novel-coronavirus-covid-19-infections/clinical-guidance/[CrossRef]

3. American Academy of Pediatrics. 2019 Novel Coronavirus COVID-19 Infections: Guidance on Provididng Pediatric Well Care During COVID-19. Available from: https://www.aap.org/en/pages/2019-novel-coronavirus-covid-19-infections/clinical-guidance/guidance-on-providing-pediatric-well-care-during-covid-19/[CrossRef] 